\title{
IMPLEMENTASI ALGORITMA WEIGHTED TREE SIMILARITY PADA APLIKASI TERJEMAHAN HADITS MUTTAFAQUN ALAIHAL LU'LU' WAL MARJAN
}

\author{
Muhammad Fahri ${ }^{1}$, Hendra Bayu Suseno ${ }^{2}$, Anif Hanifah Setyaningrum ${ }^{3}$ \\ Prodi Teknik Informatika, Fakultas Sains dan Teknologi \\ UIN Syarif Hidayatullah Jakarta \\ assegafahri253@gmail.com, hendra.bayu@uinjkt.ac.id, anif.hanifa@uinjkt.ac.id
}

\begin{abstract}
ABSTRAK
Berdasarkan wawancara yang dilakukan penulis dengan mubaligh sebagai narasumber, $A l$ Lu'lu' Wal Marjan adalah kitab yang menjadi referensi utama di kalangan mubaligh dan umat muslim karena tingkat keshahihannya yang tinggi. Walaupun kitab Al Lu'lu' Wal Marjan menjadi refensi utama, kuesioner yang penulis sebar menunjukkan bahwa masih banyak umat muslim yang belum mengenal hadits-hadits di dalamnya. Pada umumnya penceramah selama ini menggunakan kitab sebagai dasar ceramahnya. Hal ini dirasa mempersulit penceramah karena kitab membutuhkan ruang, berat dan tidak praktis dalam melakukan pencarian. pemakalah bermaksud mendigitalisasikan kitab $A l$ Lu'lu' Wal Marjan kedalam aplikasi untuk membantu mubaligh menyampaikan dalil dan Juga mengenalkan hadit-hadits muttafaqun alaih kepada umat muslim pada umumnya. jumlah hadits di dalam kitab Al Lu'lu' Wal Marjan mencapai 1906 hadits, maka dibutuhkan metode pencarian kata dengan hasil pencarian yang cepat serta dapat menyajikan urutan kemiripan untuk memberikan pilihan. Algoritma Weighted Tree Similarity yang mengelompokan indikator pencarian dengan bobot, algoritma Boyer Moore yang mencocokan keyword dengan teks Serta rumus consine yang menghitung nilai kesamaan antara tree berbobot dari keyword dengan tree database, mampu menghasilkan urutan kemiripan dengan total bobot yang diurutkan secara decending dari data yang mendekati pencarian sampai yang jauh dari data pencarian.
\end{abstract}

Kata Kunci: Hadits, Muttafaqun Alaih, algoritma Weighted Tree Similarity, algoritma Boyer Moore, Consine

\begin{abstract}
Based on interviews conducted by the author with a preacher as a resource, $\mathrm{Al} \mathrm{Lu'lu} \mathrm{'Wal} \mathrm{Marjan} \mathrm{is} \mathrm{a}$ book that became the main reference in the Muslim and Muslim preachers because of high level of highness. Even the book of Al Lu'lu 'Wal Marjan became the main reference, the questionnaire writers spread, indicating that there are still many Muslims who have not know hadith - hadith didi. In general, preachers have been using the book as the basis of his speech. This makes it difficult for speakers because the book needs space, weight and is not practical in searching. the devil's devotees digitized the book of Al Lu'lu 'Wal Marjan to the application to help preachers submit their theorem and also introduce the hadits of muttafaqun alaihong Muslim in general. the number of hadiths in the book of Al Lu'lu 'Wal Marjan reached 1906 hadith, then used to find the choice. Algorithm Moving Tree Similarity that categorizes the search indicator by weight, the Boyer Moore algorithm matching the keyword with text And the consine formula that calculates the price between the weighted tree of the keyword with the tree database, is able to generate a sequence of similarities with the accurately ranked total weight of the remote data from search data.
\end{abstract}

Keywords: Hadith, Muttafaqun Alaih, Weighted Tree Similarity Algorithm, Boyer Moore algorithm, Consine.

http://dx.doi.org/10.15408/jti.v11i2.7776 


\section{PENDAHULUAN}

Hadits yang disepakati oleh imam Bukhari dan imam Muslim disebut muttafaqun alaih. Syaikh Muhammad Fuad Abdul Baqi pada tahun 1903 mengumpulkan 1906 hadits muttafaqun alaih kedalam kitab yang diberi judul Al Lu'lu' Wal Marjan. Berdasarkan wawancara yang dilakukan penulis dengan mubaligh sebagai narasumber, $\mathrm{Al} \mathrm{Lu'lu'} \mathrm{Wal}$ Marjan adalah kitab yang menjadi referensi utama di kalangan umat muslim karena tingkat keshahihannya yang tinggi. Walaupun kitab $A l$ Lu'lu' Wal Marjan menjadi refensi utama, kusioner yang penulis sebar menunjukkan bahwa masih banyak umat muslim yang belum mengenal hadits-hadits di dalamnya. Di antaranya dari 20 reponden didapat dengan metode simple random sampling, $40 \%$ reponden belum pernah membaca hadits Jibril yang di dalam terdapat iman Islam dan ihsan. $75 \%$ reponden belum pernah membaca hadits keutamaan sahabat utama seperti Abu Bakar r.a. dan Umar ibnu Khattab r.a. dan 20\% reponden belum pernah membaca hadits tentang sunnah-sunnah kehidupan sehari-hari Nabi SAW seperti cara makan, memakai sendal dan lain-lain.

Pada penelitian ini, algoritma Weighted Tree Similarity dibentuk berdasarkan struktur kitab Al Lu'lu' Wal Marjan. Algoritma Weighted Tree Similarity digunakan untuk mencari nilai keserupaan antara keyword pencarian dari user dengan ketersediaan database hadits di kitab $A l$ Lu'lu' Wal Marjan. Pembobotan diinput oleh user untuk menekankan prioritas pencarian pada salah satu leaf node. Hasil pencarian menyajikan urutan kemiripan berdasarkan bobot secara decending (besar ke kecil) untuk mempermudah user memilih hadits yang dimaksud dari daftar pencarian. Kontribusi dari penelitian ini adalah untuk mempermudah mubaligh dan umat muslim dalam membaca dan melakukan pencarian hadist.

\section{TINJAUAN PUSTAKA}

\subsection{Muttafaqun Alaih Al Lu'lu' Wal Marjan}

Muhammad bin Ismail Al Bukhari lahir tahun 194H dan Muslim bin Al Hajjaj bin Muslim Al-Qusyairi An Nasaisaburi lahir tahun $204 \mathrm{H}$ merupakan dua orang periwayatan hadits. Hadits yang disepakati oleh dua periwayat hadits tersebut disebut bukhari muslim atau muttafaqun alaih. Kitab Al Lu'lu' Wal Marjan berisi kumpulan hadits muttafaqun alaih. Kitab ini terdiri dari 54 kitab dan 1906 hadits dalam urutan penyusunannya, nama kitab, bab serta penomorannya berdasarkan kitab Shahih Muslim. Dalam hal redaksi matan dan hadits, penyusun kitab ini mengambil dari kitab Shahih Bukhari. Kitab $A l$ Lu'lu' Wal Marjan disusun oleh Muhammad Fuad Abdul Baqi bin Shalih bin Muhammad. Beliau lahir di Mesir di desa Balqilyubiyah $1299 \mathrm{H}$ dan tumbuh besar di Kairo.

Pada tahun 2013 PT Fathan Prima Media menerbitkan kitab $\mathrm{Al} \mathrm{Lu'lu'} \mathrm{Wal} \mathrm{Marjan} \mathrm{dalam}$ terjemahan Indonesia dengan judul Hadits Shahih Bukhari Muslim. Cetakan keenam diterbitkan pada tahun 2016 berdasarkan terjemahan dari Abu Firly Taqiy.

\section{a. Weighted Tree Similarity}

Tree adalah salah satu struktur data untuk representasi pengetahuan dengan membentuk hierarki struktur pohon dengan sejumlah node yang saling berhubungan. Bentuk dasar tree ditunjukan gambar di bawah ini. Sebuah node dapat mengandung nilai, kondisi, atau data. Setiap node tidak harus memiliki child node.

Node yang tidak memiliki anak disebut leaf node. Sebuah node hanya memiliki parent node. Simpul yang paling atas dalam tree adalah root. Root tidak memiliki parent. Internal root atau inner node adalah sebuah node yang memiliki child. External node atau outer node adalah sebuah node yang tidak memiliki child node atau external node adalah leaf node. Tinggi sebuah tree adalah panjang maksimal dari root ke leaf node. Kedalaman sebuah node adalah jarak root ke node tersebut.

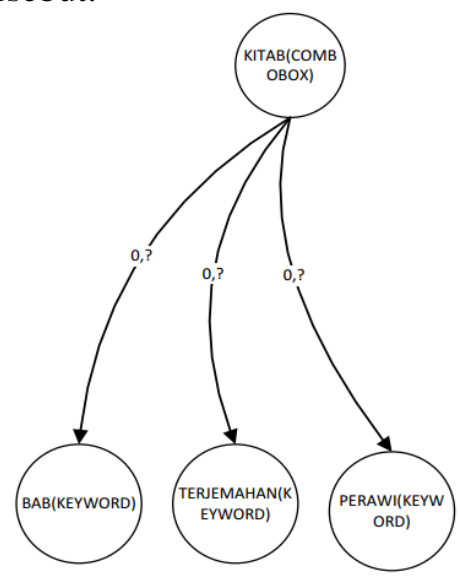

Gambar 1. Algoritma Weighted Tree Similarity 
Weighted Tree Similarity adalah algoritma yang digunakan untuk mengukur kemirian dua buah tree. Weighted Tree Similarity pada awalnya adalah agen pada $e$ business untuk mencocokkan atau mendapatkan keinginan buyer dan persediaan seller yang paling mirip melalui weighted tree sebagai bentuk representasi.

Dalam marketplace, buyer dan seller mengiklankan kebutuhan dan penawaran produk/jasa mereka. Untuk mendapatkan kecocokan antara keduanya, perhitungan kemiripan antara penawaran dan permintaan harus menghasilkan daftar kemiripan terurut untuk buyer dan seller.

Weighted tree memiliki konsep node belabel, arc berlabel, dan arc berbobot untuk merepresentasikan relasi parent-child dari suatu atribut. Arc berlabel menunjukan atribut dan bobot arc menunjukan tingkat kepentingan dari arc. Ada banyak metode dalam pencocokan leaf node diantaranya String Maching Boyer Moore dan Consine Similarity. Berikutnya setelah di dapat bobot dari setiap vektor, bobot diurutkan secara decending.

\section{b. Pencarian Kata}

Robert Stephen Boyer (Bob Boyer), dan J. Strother Moore pada tahun 1977 mempublikasikan algoritma Boyer Moore yaitu salah satu algoritma yang digunakan untuk pencarian string. Boyer Moore dianggap sebagai algoritma yang paling efisien pada aplikasi umum. Berbeda dengan algoritma pencarian string lain yang telah ada sebelumnya, Boyer Moore mulai mencocokkan karakter dari sebelah kanan pattern.

Ide utama dari algoritma ini adalah dengan melakukan pencocokan dari paling kanan string yang dicari. Dengan menggunakan algoritma ini, secara rata-rata proses pencarian akan lebih cepat dibandingkan dengan proses pencarian lainnya. Ide dibalik algoritma ini adalah bahwa dengan memulai pencocokan karakter dari kanan, dan bukan dari kiri, maka akan lebih banyak informasi yang didapat (Mufthy, 2011).

Ide dari algoritma adalah dengan menggunakan pengetahuan tentang pencarian teks untuk meningkatkan kecepatan pencarian secara signifikan. Algortima Boyer Moore menggunakan suatu langkah sebelum proses untuk membuat Occurance Heuristic dan Shifting Function yang digunakan untuk melakukan Bad
Character Heuristic dan Good Suffix Heuristic. (Prabhakar Gupta, et al. 2010)

Boyer Moore menggunakan dua heuristik untuk memutuskan seberapa jauh melompat: Bad Character Heuristic sering disebut Occurrence Heuristic, dan heuristik yang Good Character disebut Match Heuristic. Informasi untuk heuristik setiap dipertahankan dalam sebuah array yang dibangun pada awal operasi yang cocok. (Jon Orwant, et al, 1999).

Secara sistematis, langkah-langkah yang dilakukan algoritma Boyer Moore pada saat mencocokkan string adalah:
1. Algoritma Boyer-Moore mulai mencocokkan pattern pada awal teks.

2. Dari kanan ke kiri, algoritma ini akan mencocokkan karakter per karakter pattern dengan karakter di teks yang bersesuaian, sampai salah satu kondisi berikut dipenuhi:

a. Karakter di pattern dan di teks yang dibandingkan tidak cocok (mismatch).

b. Semua karakter di pattern cocok. Kemudian algoritma akan memberitahukan penemuan di posisi ini.

3. Algoritma kemudian menggeser pattern dengan memaksimalkan nilai penggeseran good-suffix dan penggeseran bad-character, lalu mengulangi langkah 2 sampai pattern berada di ujung teks.

\section{c. Perhitungan Kemiripan}

Consine Similarity adalah ukuran kesamaan yang lebih umum digunakan dalam information retrieval dan merupakan ukuran sudut antara vektor dokumen $\mathrm{Da}(\operatorname{titik}(\mathrm{ax}, \mathrm{bx}))$ dan $\mathrm{Db}$ (titik(ay,by)). Tiap vektor tersebut merepresentasikan setiap kata dalam setiap dokumen teks yang dibandingkan antara dua buah weighted tree.

$\operatorname{Cosine}(q, d)=\frac{\sum_{k=1}^{m} w_{q k} \times w_{d k}}{\sqrt{\sum_{k=1}^{m}\left(w_{q k}\right)^{2}} \cdot \sqrt{\sum_{k=1}^{t}\left(w_{d k}\right)^{2}}}$

Ketika dua dokumen identik, nilainya adalah 1 ketika dua dokumen tidak identik sama sekali, nilainya adalah 0 . 


\section{METODOLOGI}

Dalam penyebaran kuisioner penulis menggunakan google form dibatasi 20 responden secara acak. Pengambilan sampel responden dalam penyebaran kuesioner, penulis menggunakan teknik Simple Random Sampling. Dari kuisioner didapat beberapa kesimpulan di antaranya:

1. $100 \%$ responden pengguna OS Android.

2. $90 \%$ responden berkeinginan menginstall hadits muttafaq 'alaih.

3. $40 \%$ reponden belum pernah membaca hadits tentang rukun agama.

4. $20,8 \%$ responden belum pernah membaca hadits-hadits yang berkaitan dengan sunnah sehari-hari seperti sunnah memakai sandal, sunnah tata cara makan dan sunnah lain-lainnya.

5. $75 \%$ reponden tidak pernah membaca hadits tentang keutamaan sahabat.

Berdasarkan wawancara yang dilakukan penulis dengan mubaligh sebagai narasumber, al-Lu'lu' wa al-Marjan adalah kitab yang menjadi referensi utama dikalangan mubaligh dan umat muslim karena tingkat keshahihannya yang tinggi. Walaupun kitab alLu'lu' wa al-Marjan menjadi refensi utama, kusioner yang penulis sebar, menunjukkan bahwa masih banyak umat muslim yang belum mengenal hadits-hadits di dalamnya. Pada umumnya penceramah selama ini menggunakan kitab sebagai dasar ceramahnya. Hal ini dirasa mempersulit penceramah karena kitab membutuhkan ruang, berat dan tidak praktis dalam melakukan pencarian.

Dari uraian di atas, peneliti bermaksud mendigitalisasikan kitab al-Lu'lu' wa alMarjan ke dalam aplikasi android untuk membantu mubaligh menyampaikan dalil. Juga mengenalkan hadit - hadits muttafaq alaih kepada umat muslim pada umumnya. jumlah hadits didalam kitab alLu'lu' wa al-Marjan mencapai 1906 hadits maka dibutuhkan metode pencarian kata dengan hasil pencarian cepat serta dapat menyajikan urutan kemiripan mulai dari yang paling mirip/mendekati data pencarian hingga yang paling jauh dari data pencarian

\section{HASIL DAN PEMBAHASAN}

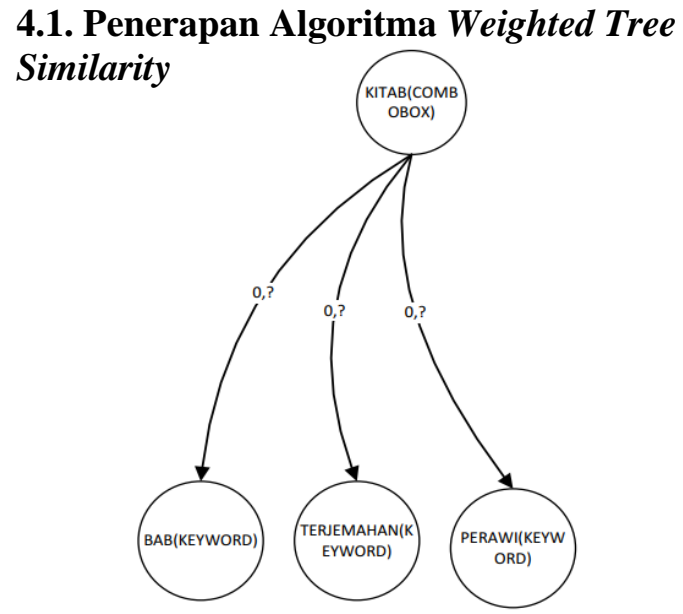

Gambar 2. Algoritma Weighted Tree Similarity

Algoritma Weighted Tree Similarity adalah sebuah algoritma untuk mencari nilai keserupaan(similarity) dengan menggunakan bentuk tree yang berbobot. Pada gambar 2 terlihat bahwa, bentuk tree dari kitab al-Lu'lu' wa al-Marjan memiliki node berlabel diantaranya root node kitab, leaf node bab, perawi dan terjemahan. bobot diinput oleh user sebagai penekanan prioritas pada salah satu leaf node. Proses Weighted Tree Similarity pada kitab alLu'lu' wa al-Marjan dimulai dari user mengklik menu cari. Selanjutnya user akan disajikan 1 combobox atau lebih di kenal di android sebagai spinner bersikan judul-judul kitab dan 3 textbox di antaranya berisikan bab, perawi, terjemahan. User memilih kitab dan menginput keyword ke dalam 3 textbox, dilanjutkan dengan mengklik button cari. Jika semua hadits-hadits yang didalam kitab yang dipilih tidak ada kandungan keyword dari 3 textbox yang diinput maka sistem akan mengakhiri proses dengan menampilkan bobot nol dari haditshadits yang terdapat dari kitab yang dipilih. Jika tidak, maka sistem akan melakukan proses pencarian dengan algoritma Boyer Moore di masingmasing leaf node dimulai dari leaf node bab, jika terdapat keyword leaf node bab di salah satu hadits maka sistem akan menyisipkan bobot. Begitu juga dengan leaf node perawi dan terjemahan. Berikutnya sistem akan melakukan proses perhitungan total bobot dengan Consine Similarity. Terakhir user akan disajikan hadits dengan bobot yang diurutkan secara decending(besar ke kecil) untuk memudahkan user memilih hadits yang dinginkan. 
Berikut simulasi dari proses algoritma Weighted Tree Similarity. Misalkan user memilih semua kitab di spinner. Berikutnya keyword untuk bab yakni wudhu dengan bobot 0.32 , keyword untuk perawi yakni Ali dengan bobot 0.13 dan keyword untuk terjemahan yakni membasuh dengan bobot 0.45 . Selanjutnya sistem akan melakukan proses pencarian kata dengan algoritma Boyer Moore dan perhitungan bobot dengan rumus Consine Similarity. Berikut adalah penjelasan rinci tentang proses pencarian kata dan perhitungan bobot:

\subsubsection{Proses Pencarian Kata dengan Algoritma Boyer Moore}

Algoritma Boyer Moore memulai pencocokan karakter dari kanan. Dimisalkan ada sebuah usaha pencocokan yang terjadi pada text[i..i+n-1], anggap ketidakcocokan pertama terjadi di antara text $[\mathrm{i}$ $+\mathrm{j}$ ] dan pattern[j], dengan $0<\mathrm{j}<\mathrm{n}$. Berarti, teks $[\mathrm{i}+\mathrm{j}+1 . . \mathrm{i}+\mathrm{n}-1]=\operatorname{pattern}[\mathrm{j}+1 . . \mathrm{n}-1]$ dan $\mathrm{a}=$ teks $[\mathrm{i}+\mathrm{j}]$ tidak sama dengan $\mathrm{b}=$ pattern[j]. Secara sistematis langkah-langkah yang dilakukan sebagai berikut:

1. Langkah pertama mencari nilai
table(penggeseran karakter) dari

Occurance Heuristic/ MakeCharTable dan Match Heuristic/MakeOffset table. Berikut sampel kodingan dari MakeCharTable dan MakeOffsetTable.

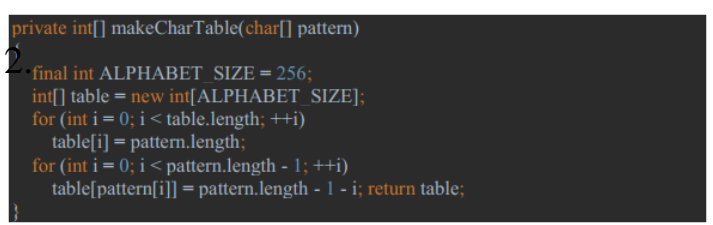

Diperoleh rumus table OH/MakeCharTable

\begin{tabular}{|c|r|r|r|r|r|r|r|r|r|}
\hline \multicolumn{10}{|c|}{ BAB } \\
\hline INDEX & W & U & D & H & $*$ & & & \\
\hline TABLE & 5 & 4 & 3 & 2 & 5 & & & \\
\hline \multicolumn{10}{|c|}{ TERAWI } \\
\hline INDEX & A & L & $*$ & & & & & \\
\hline TABLE & 2 & 1 & 3 & & & & & \\
\hline \multicolumn{8}{|c|}{ TERJEMAHAN } \\
\hline INDEX & M & E & M & B & A & S & U & $*$ \\
\hline TABLE & 5 & 6 & 5 & 4 & 3 & 2 & 1 & 8 \\
\hline
\end{tabular}

M. Fahri, dkk: Implementasi Algoritma....

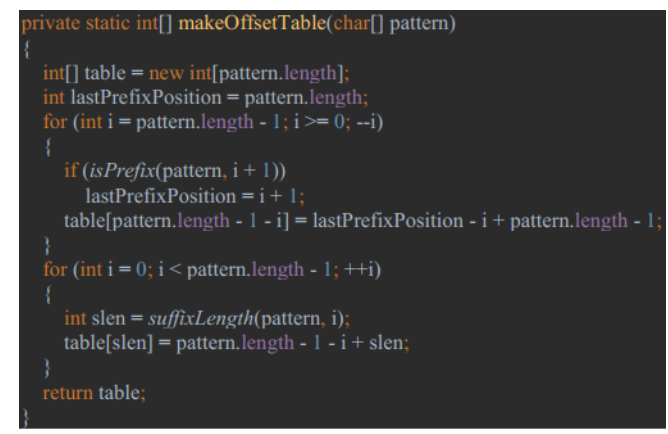

Diperoleh rumus table MH/MakeOffsetTable

\begin{tabular}{|r|r|r|r|r|r|r|r|r|r|}
\hline \multicolumn{7}{|c|}{ BAB } \\
\hline INDEX & 0 & 1 & 2 & 3 & 4 & & & \\
\hline TABLE & 1 & 4 & 7 & 8 & 9 & & & \\
\hline \multicolumn{7}{|c|}{ PERAWI } \\
\hline INDEX & 0 & 1 & 2 & & & & & \\
\hline TABLE & 1 & 4 & 5 & & & & & \\
\hline \multicolumn{10}{|c|}{ TERJEMAHAN } \\
\hline INDEX & 0 & 1 & 2 & 3 & 4 & 5 & 6 & 7 \\
\hline TABLE & 1 & 9 & 10 & 11 & 12 & 13 & 14 & 15 \\
\hline
\end{tabular}

3. Langkah kedua pencocokan pattern dengan text menggunakan rumus table (penggeseran karakter)

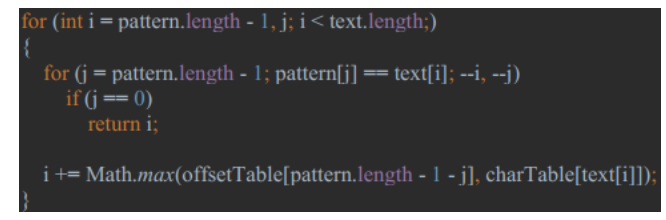

Berikut pola penggeseran text dan pattern di dalam for untuk pencarian kata dalam bab:

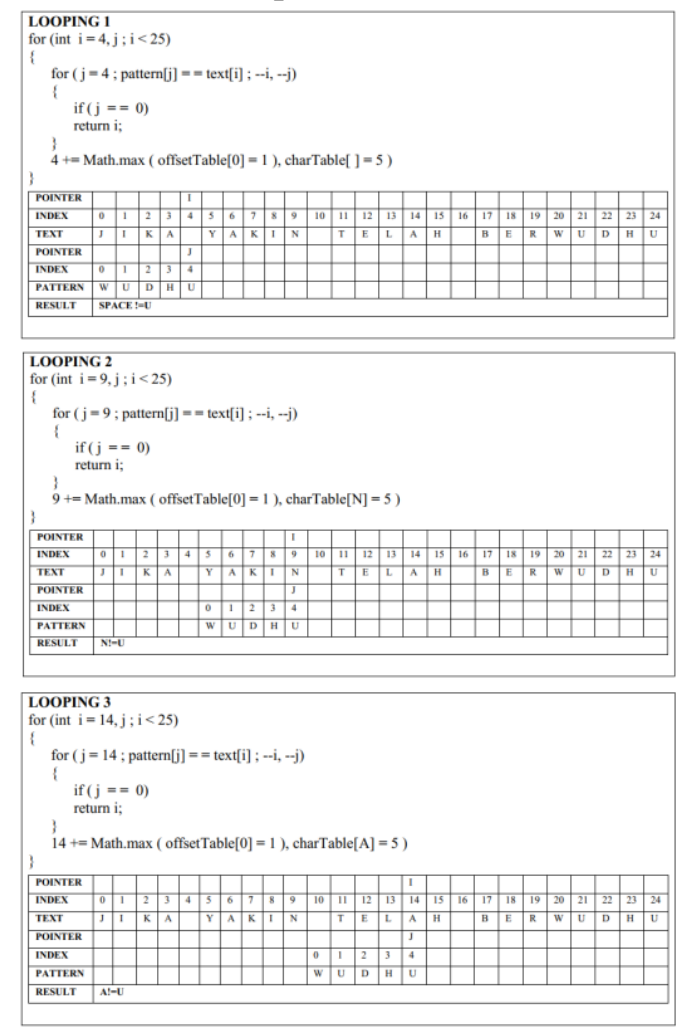




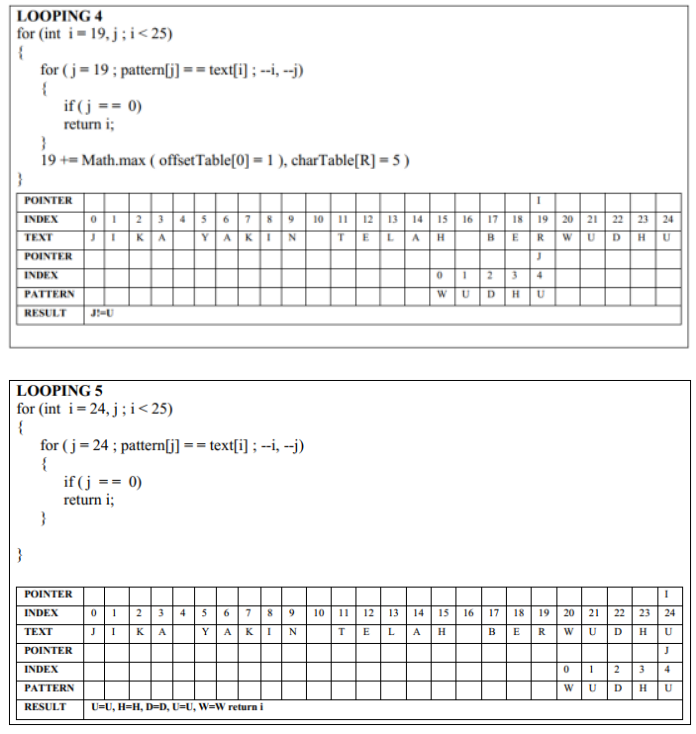

Berikut pola penggeseran text dan pattern di dalam for untuk pencarian kata dalam perawi:

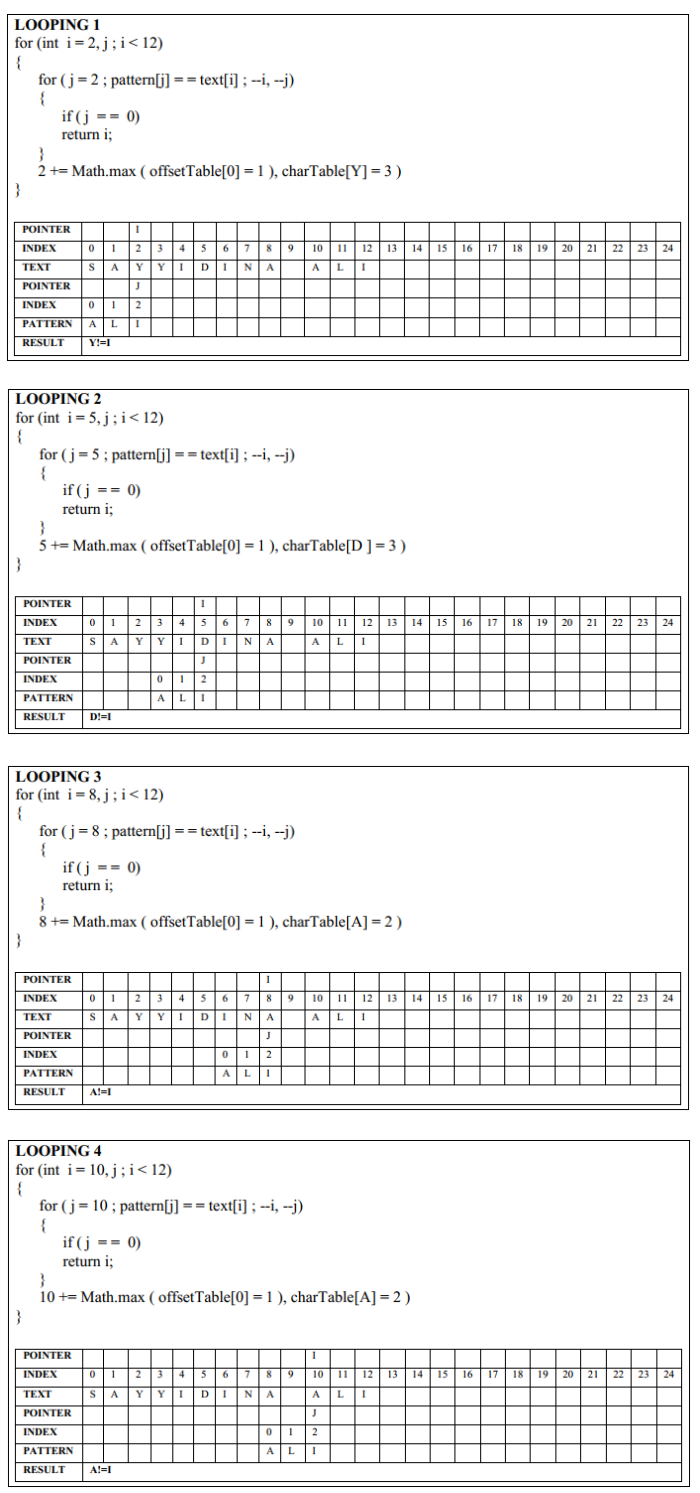

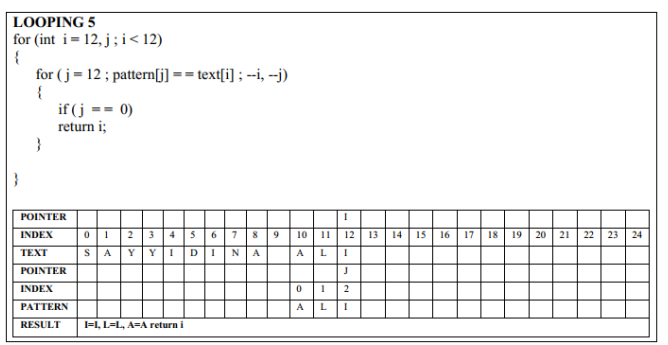

Berikut pola penggeseran text dan pattern di dalam for untuk pencarian kata dalam terjemahan:

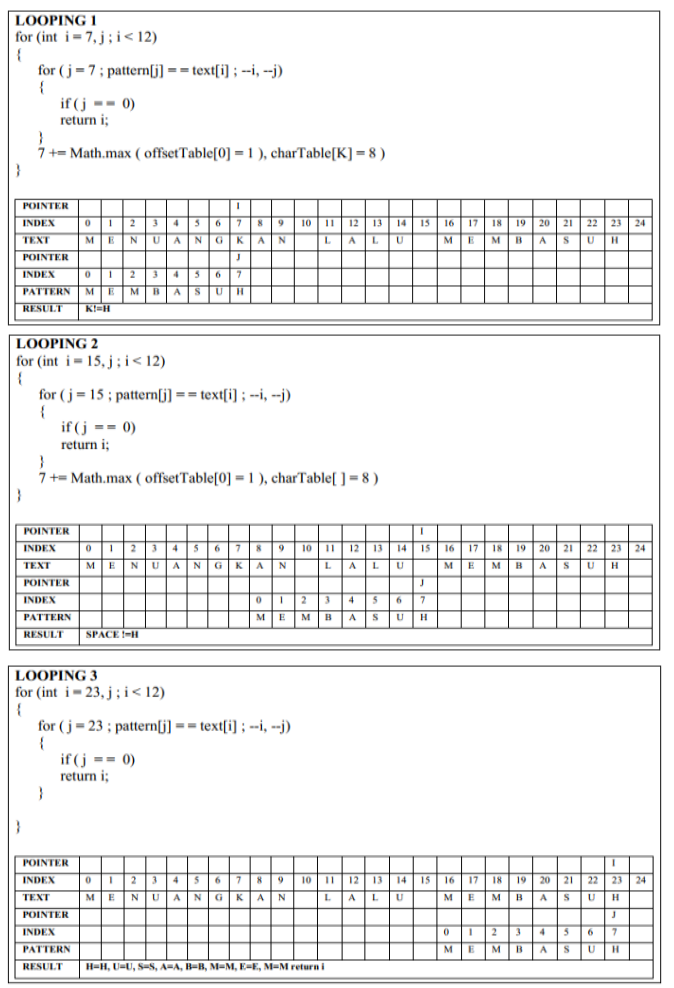

\subsubsection{Proses Perhitungan Dengan Consine}

Setelah pada tahap sebelumnya proses pencocokan dengan algoritma boyer moore antara keyword dengan database.Vektor d mewakili keyword dan vektor q mewakili database. Dimensi yang tidak ada di salah satu vektor diadakan dengan bobot 0. Berikut adalah contoh akumuasi antara vektor d dengan vektor q. Bobot dengan nilai 0.45 untuk terjemahan, 0.13 untuk bab dan 0.32 untuk perawi. Di bawah ini adalah bentuk vektor tree dari keyword dan vektor tree dari database

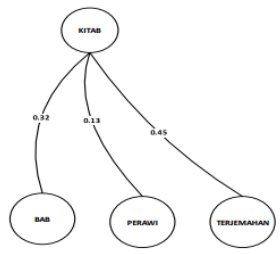

D

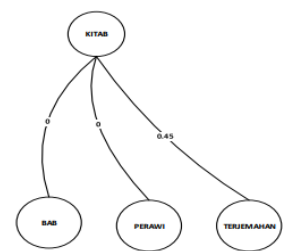

Q
Gambar 3. Proses perhitungan dengan consine 
Berikut adalah hasil perhitungan dua vektor tree di atas

$$
\begin{aligned}
& \text { Consine }(\mathrm{q}, \mathrm{d})=\frac{\sum_{k=1}^{m} \mathrm{wqk} * \mathrm{wdk}}{\sqrt{\sum_{k=1}^{m}(w q k)^{2}} \cdot \sqrt{\sum_{k=1}^{m}(w d k)^{2}}} \\
& \operatorname{Consine}(\mathrm{q}, \mathrm{d})=\frac{(0.32 * 0.32)+(0.13 * 0.13)+(0.45 * 0.45)}{\sqrt{0.32^{2}+0.13^{2}+0.45^{2}} \cdot \sqrt{0.32^{2}+0.13^{2}+0.45^{2}}} \\
& \text { Consine }(\mathrm{q}, \mathrm{d})=0.79
\end{aligned}
$$

Berikut adalah rumus consine yang diterjemahan dalam bentuk coding

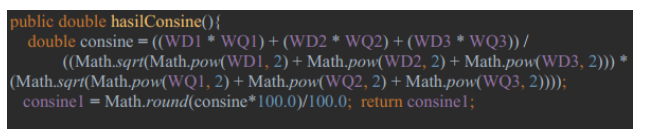

\subsubsection{Flowchart Weighted Tree Similarity}

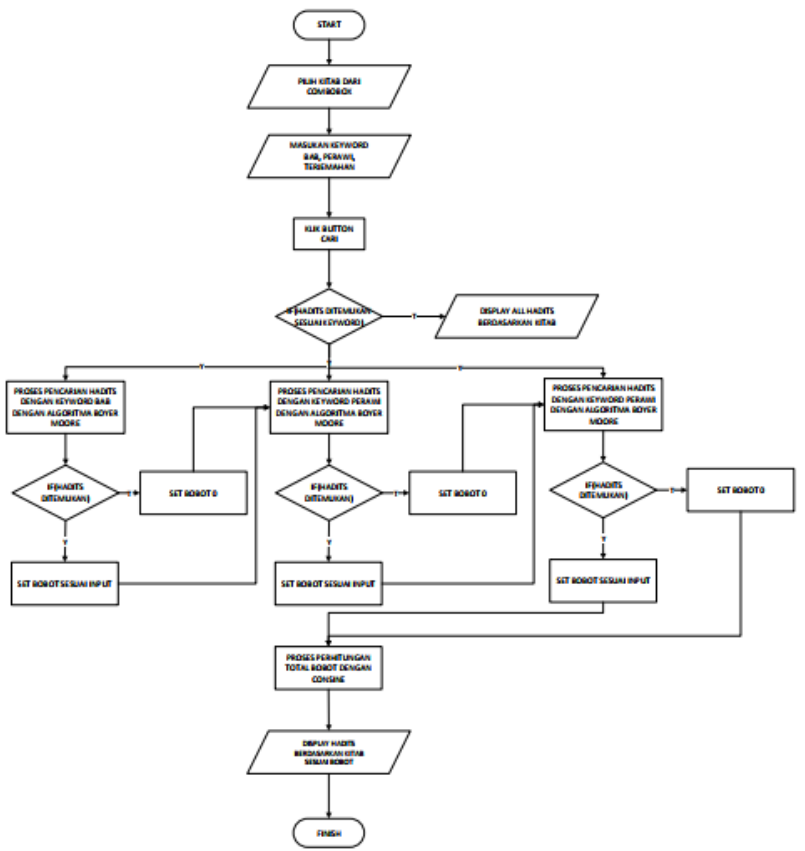

Gambar 4. Flowchart weighted tree similarity

Berikut adalah gambaran flowchart secara rinci dari proses Boyer Moore dan consine yang terdapat pada algoritma Weighted Tree Similarity:

1. Flowchart pencarian kata dengan algoritma Booyer Moore.

2. Flowchart perhitungan total bobot dengan rumus Consine

\subsubsection{Flowchart Pencarian Kata dengan Boyer Moore}

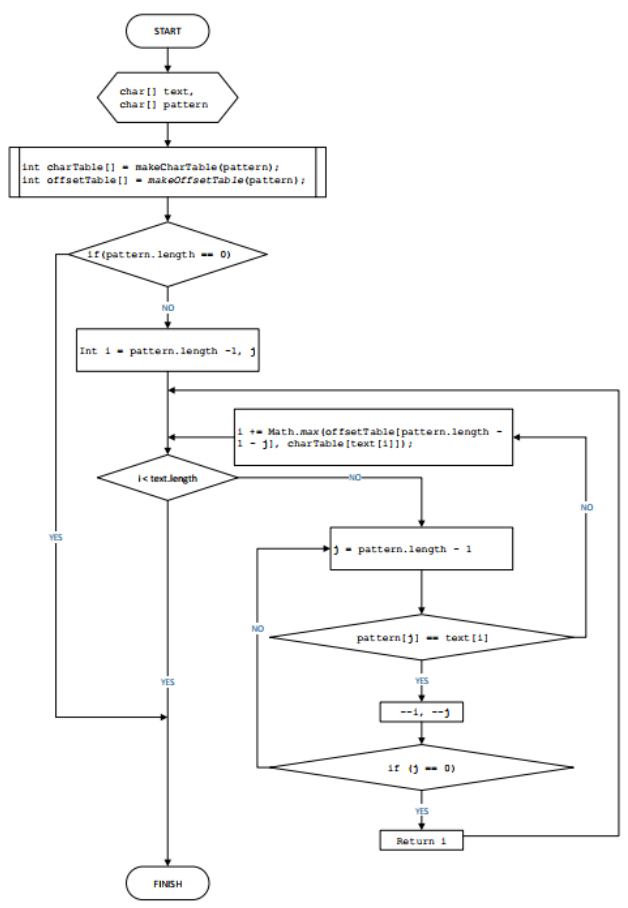

Gambar 5. Flowchart Boyer Moore

\subsubsection{Flowchart Perhitungan Dengan} Consine

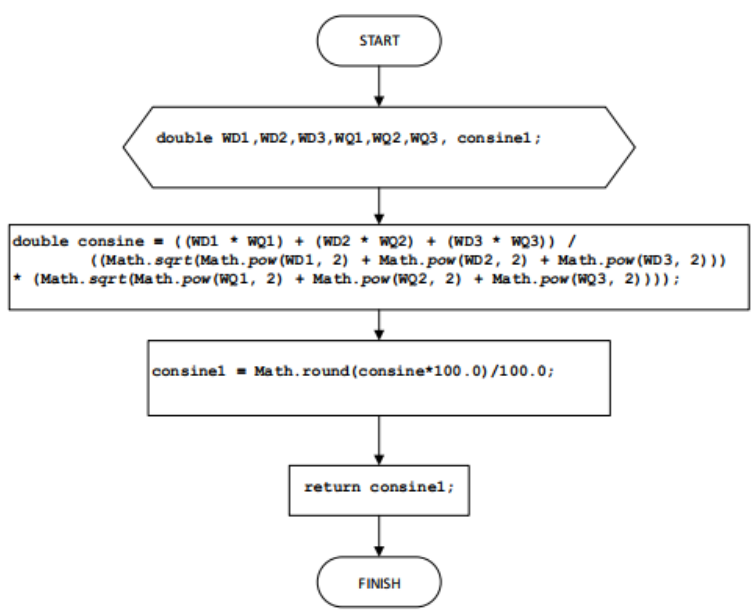

Gambar 6. Flowchart consine 


\subsection{Perancangan model UML}

\subsubsection{Use Case Diagram}

Pada tahap pertama dengan merancang diagram Use Case. Pada diagram ini dapat terlihat interaksi antara sistem dan pengguna. Berikut ini adalah spesifikasi Use Case:

1. Identifikasi Aktor

Pengidentifikasian terhadap aktor (pengguna) agar sistem dapat digunakan sesuai kebutuhan. Berikut ini identifikasi aktor pada aplikasi:

Tabel 1. Identifikasi aktor

\begin{tabular}{|c|l|l|}
\hline No. & \multicolumn{1}{|c|}{ Aktor } & \multicolumn{1}{c|}{ Deskripsi } \\
\hline 1 & User & $\begin{array}{l}\text { Orang yang membaca atau mencari } \\
\text { Hadits muttafaqun alaih dengan } \\
\text { bantuan aplikasi ini }\end{array}$ \\
\hline
\end{tabular}

2. Identifikasi Use Case

Tabel 2. Identifikasi use case

\begin{tabular}{|c|l|l|}
\hline No. & \multicolumn{1}{|c|}{ Use Case } & \multicolumn{1}{|c|}{ Deskripsi } \\
\hline 1 & Lihat Daftar Kitab & Menampilkan daftar kitab dari database \\
\hline 2 & Lihat Daftar Bab & $\begin{array}{l}\text { Menampilkan daftar bab dari database berdasarkan } \\
\text { kitab yang dipilih }\end{array}$ \\
\hline 3 & Lihat Daftar Hadits & $\begin{array}{l}\text { Menampilkan daftar Hadits dari database } \\
\text { berdasarkan bab yang dipilih }\end{array}$ \\
\hline 4 & Lihat Catatan & Menampilkan daftar Hadits yang diberi catatan \\
\hline 5 & Lihat Penanda & Menampilkan daftar Hadits yang ditandai \\
\hline 6 & Pencarian & $\begin{array}{l}\text { Menggambarkan proses pencarian Hadits yang } \\
\text { dilakukan oleh user dengan cara menginputkan } \\
\text { sebuah kata kunci ke dalam kolom pencarian }\end{array}$ \\
\hline 7 & Daftar Pencarian & $\begin{array}{l}\text { Menampilkan daftar hadits dari hasil pencarian } \\
\text { berdasarkan bobot secara decending }\end{array}$ \\
\hline 8 & Setting Bobot & Mengatur niai bobot bab, terjemahan dan perawi \\
\hline 9 & Rincian Hadits & $\begin{array}{l}\text { Menampilkan isi konten hadits dari database } \\
\text { berdasarkan Hadits yang diilih melalui daftar } \\
\text { pencarian, lihat penanda, lihat catatan dan lihat } \\
\text { daftar Hadits }\end{array}$ \\
\hline
\end{tabular}

3. Use Case Diagram

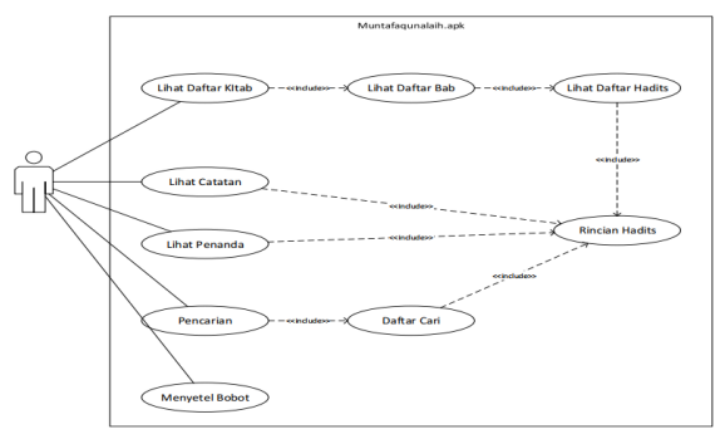

Gambar 7. Use case diagram

\subsubsection{Activity Diagram}

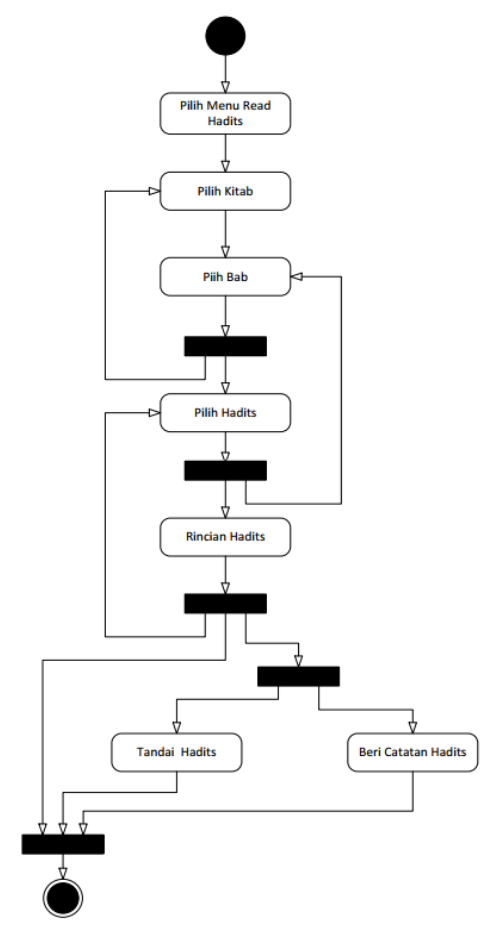

Gambar 8. Activity diagram read hadits

Pada Gambar 8 terlihat bahwa pemilihan rincian hadits tergantung dari pemilihan hadits, pemilihan hadits tergantung dari pemilihan bab dan pemilihan bab tergantung dari kitab yang dipilih. Selain proses read hadits dari kitab sampai rincian hadits, terdapat juga proses bookmark dan quotes di rincian hadits.

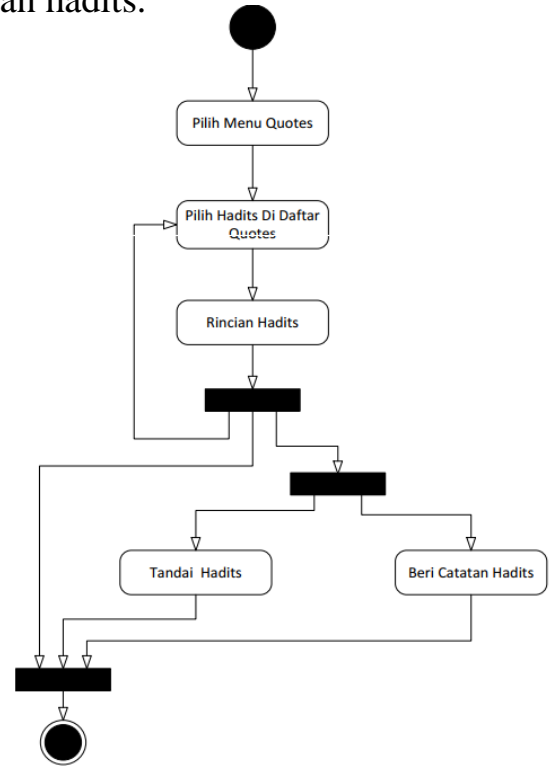

Gambar 9. Activity diagram quotes

Pada Gambar 9 terlihat bahwa user dapat melihat daftar hadits yang 
diberi catatan sebelumnya. ListView catatan yang diklik user merujuk pada rincian hadits.

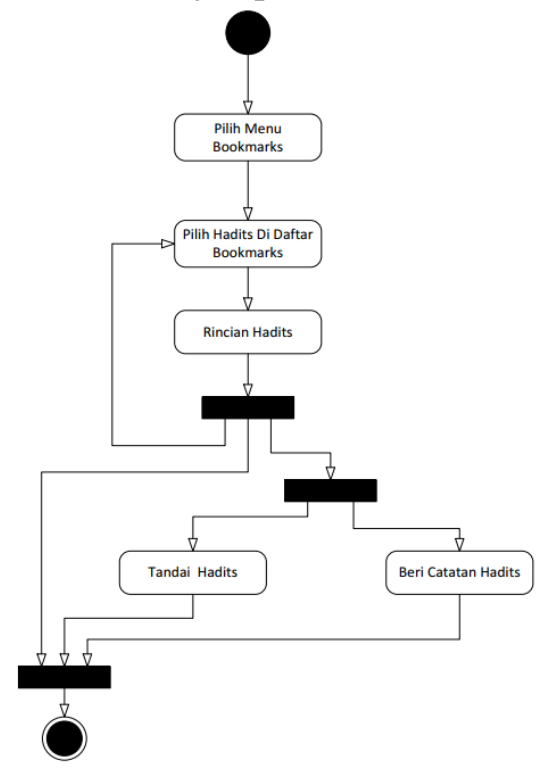

Gambar 10. Activity diagram bookmark

Pada Gambar 10 terlihat bahwa user dapat melihat daftar hadits yang diberi tanda sebelumnya. ListView bookmark yang diklik user merujuk pada rincian hadits.

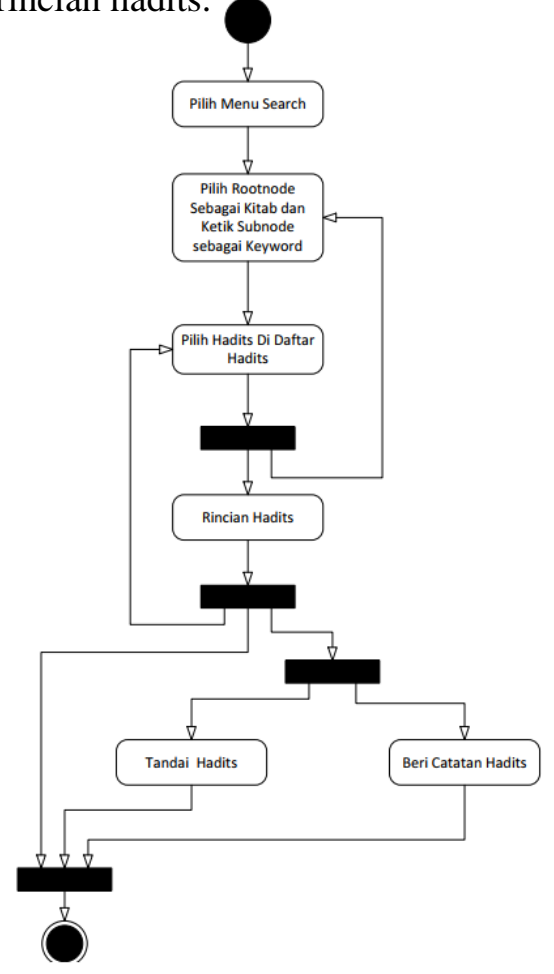

Gambar 11. Activity diagram search hadits

Pada Gambar 11 terlihat bahwa user memulai aktivitas pencarian dengan memilih root node yakni kitab dari combo box. Berikutnya memberikan keyword di masing-masing subtree yakni terjemahan, perawi dan bab.
Setelah proses input keyword dan press button search, user akan melihat daftar hadits dengan bobot yang mewakili keyword tersusun secara decending. ListView daftar hadits merujuk pada rincian hadits.

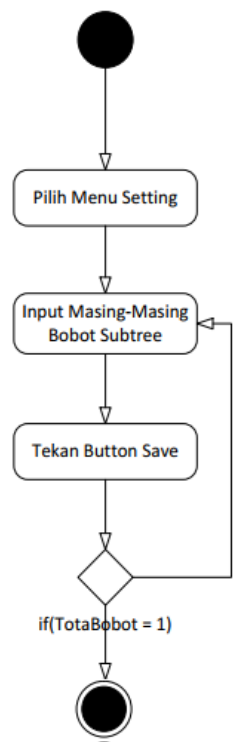

Gambar 12. Activity diagram setting

Pada gambar 12 terlihat bahwa pembobotan hanya terjadi di subtree dan total dari pembobotan harus bernilai 1.0. Hal ini mengikuti rule dari algoritma Weighted Tree Similarity dimana rood node tidak berbobot dan angka 1 mewakili maksimal keindentikan hasil pencarian.

\subsubsection{Sequence Diagram}

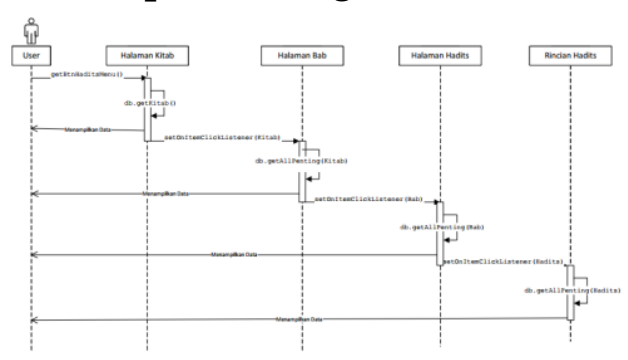

\section{Gambar 13. Sequence diagram read hadits}

Pada Gambar 13 terlihat bahwa user memulai interaksi dengan mengakses halaman kitab. Selanjutnya sistem menampilkan nama-nama kitab yang terdapat dari database dengan method db.getKitab() yang diolah. Berikutnya user memilih kitab di ListView yang merujuk pada bab berdasarkan kitab yg dipilih. Selanjutnya user memilih bab di ListView yang merujuk pada hadits berdasarkan bab yg dipilih. Terakhir sistem menampilkan rincian hadits dari rujukan hadits yang dipilih 


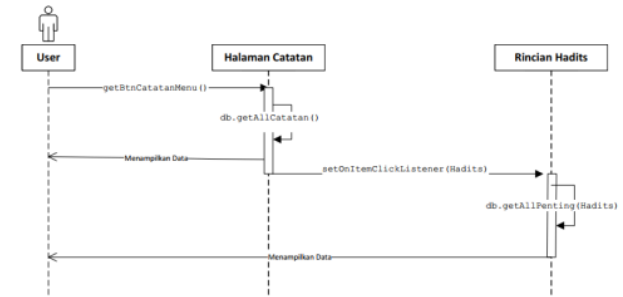

Gambar 14. Sequence diagram quotes

Pada Gambar 14 terlihat bahwa user memulai interaksi dengan mengakses halaman catatan. Selanjutnya sistem menampilkan ListView hadits yang terdapat catatan sebelumnya. ListView hadits yang diklik merujuk pada halaman rincian hadits.

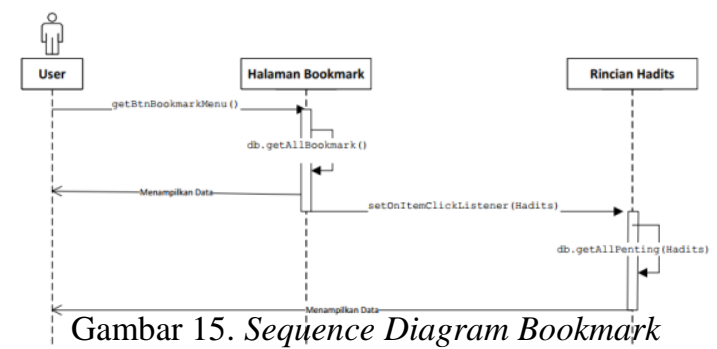

Pada Gambar 15 terlihat bahwa user memulai interaksi dengan mengakses halaman bookmark. Selanjutnya sistem menampilkan ListView hadits yang terdapat bookmark sebelumnya. ListView hadits yang diklik merujuk pada halaman rincian hadits.

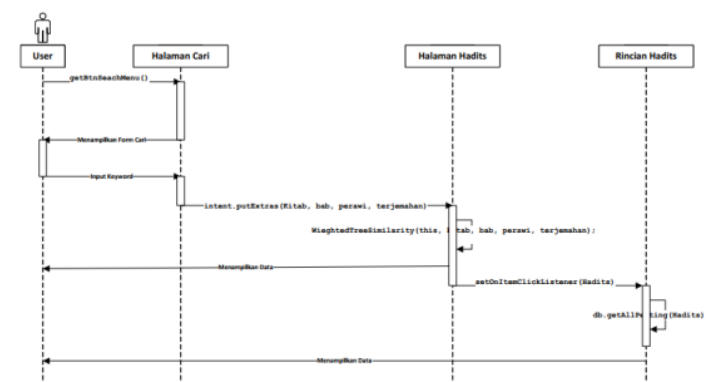

Gambar 16. Sequence diagram search hadits

Pada gambar 16 terlihat bahwa user memulai interaksi dengan mengakses halaman cari. Selanjutnya user menginput keyword baik untuk root node maupun subtree. Halaman Cari mengirim keyword dengan method intent.putExtras (Kitab, bab, perawi, terjemahan) ke halaman hadits atau daftar cari. Dan di halaman inilah keyword yang tadi dikirim diproses dengan memanggil metode algoritma induk WeightedTreeSimilarity(this, kitab, bab, perawi, terjemahan). Metode ini menghasilkan ListView hadits dengan bobot berdasarkan keyword yang diinput. ListView hadits yang diklik merujuk pada halaman rincian hadits.

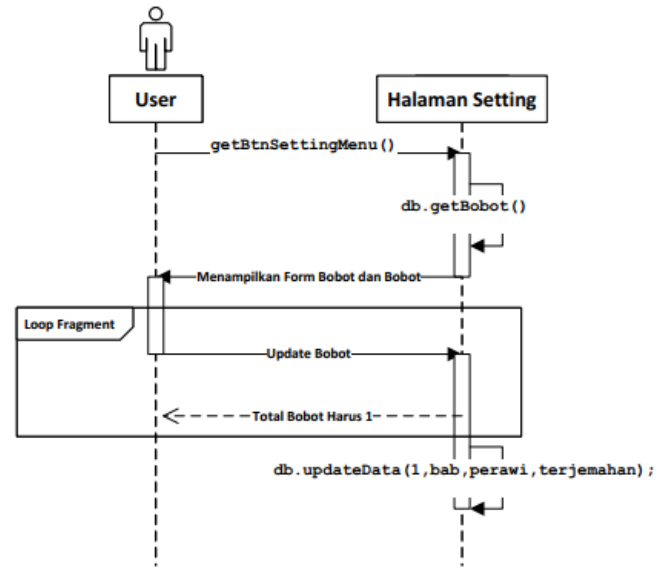

Gambar 17. Sequence diagram setting hadits

Pada gambar 17 terlihat bahwa user memulai interaksi dengan mengakses halaman Setting. Selanjutnya user menginput bobot untuk masing-masing subtree. Proses pembobotan terdapat validasi dimana akumulasi total bobot harus 1.0. Hal ini mengikuti rule dari algoritma Weighted Tree Similarity dimana root node tidak berbobot dan angka 1 mewakili maksimal keindentikan hasil pencarian.

\subsubsection{Class Diagram}

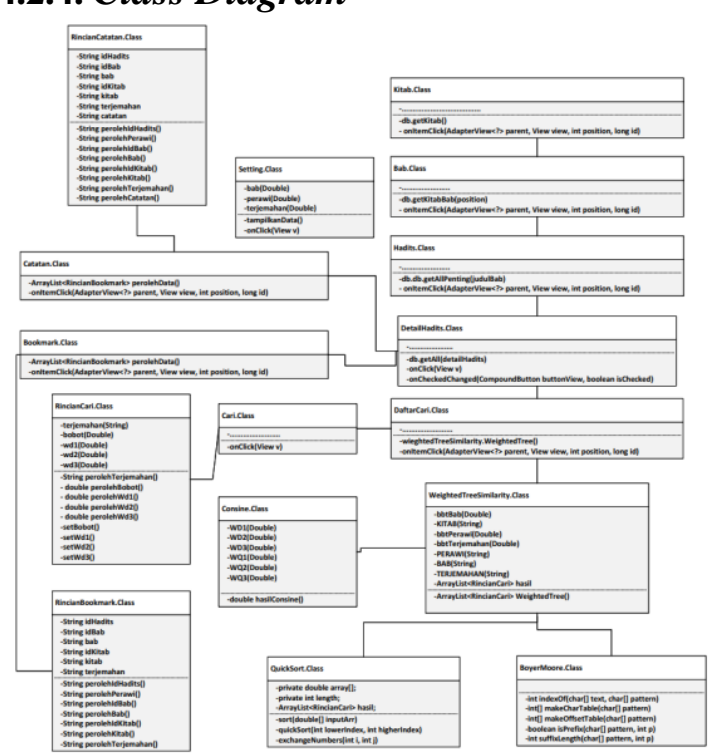

Gambar 18. Class diagram

\subsection{Pengujian}

Pengujian metode pencarian Weighted Tree Similarity Pada Aplikasi Hadits Muttafaq Alaih Al Lu'lu' Wal Marjan dilakukan dengan tiga narasumber, Android dan Operating System berbeda. 
Tabel 3.Pengujian Sistem

\begin{tabular}{|c|c|c|c|c|c|}
\hline No & Nama & Smartphone & $\begin{array}{c}\text { Operating } \\
\text { System }\end{array}$ & Keyword & $\begin{array}{c}\text { Waktu } \\
\text { Pencarian }\end{array}$ \\
\hline 1 & $\begin{array}{l}\text { Eka } \\
\text { Pramudita }\end{array}$ & Lenovo & $\begin{array}{l}5.1 \\
\text { (Lolipop) }\end{array}$ & $\begin{array}{l}\text { Iman, } \\
\text { Dosa, Ali, } \\
\text { Berdusta }\end{array}$ & $+1 \mathrm{~s} 144 \mathrm{~ms}$ \\
\hline 2 & $\begin{array}{l}\text { Hidaya } \\
\text { Sari }\end{array}$ & $\begin{array}{l}\text { Samsung- } \\
\text { J510FN }\end{array}$ & 6.0 .1() & $\begin{array}{l}\text { Iman, } \\
\text { Rukun, } \\
\text { Islam, } \\
\text { Umar, } \\
\text { Zakat }\end{array}$ & $+893 \mathrm{~ms}$ \\
\hline
\end{tabular}

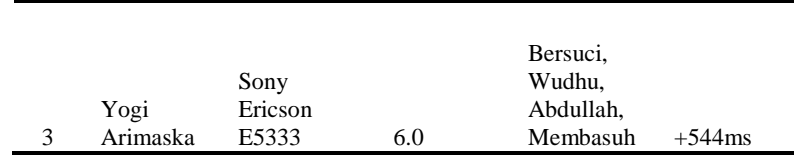

\section{Hasil Pencarian Pertama}

Berikut adalah rincinan perhitungan consine pertiap hadits berdasarkan keyword:

Tabel 4. Perhitungan Consine Pencarian pertama

\begin{tabular}{|c|c|c|c|c|c|c|c|c|c|}
\hline \multirow{2}{*}{ Hadits } & \multicolumn{3}{|c|}{ Wqk } & \multicolumn{3}{|c|}{ Wdk } & \multirow{2}{*}{$\begin{array}{l}\sum_{k=1}^{m} w q k \\
{ }^{*} w d k\end{array}$} & \multirow{2}{*}{$\sqrt{\sum_{k=1}^{m}(w q k)^{2}} \cdot \sqrt{\sum_{k=1}^{m}(w d k)^{2}}$} & \multirow{2}{*}{$\operatorname{Con}(q, d)$} \\
\hline & Q1 & Q2 & Q3 & D1 & D2 & D3 & & & \\
\hline 1 & 0.32 & 0.13 & 0.45 & 0.32 & 0.13 & 0.45 & 0.3218 & 0.3218 & 1.0 \\
\hline 2 & 0.32 & 0.13 & 0.45 & 0.32 & 0 & 0.45 & 0.3049 & 0.3132360451799888 & 0.97 \\
\hline 3 & 0.32 & 0.13 & 0.45 & 0.32 & 0 & 0.45 & 0.3049 & 0.3132360451799888 & 0.97 \\
\hline 4 & 0.32 & 0.13 & 0.45 & 0.32 & 0 & 0.45 & 0.3049 & 0.3132360451799888 & 0.97 \\
\hline 5 & 0.32 & 0.13 & 0.45 & 0 & 0 & 0.45 & 0.2025 & 0.25527338286629103 & 0.79 \\
\hline 6 & 0.32 & 0.13 & 0.45 & 0 & 0 & 0.45 & 0.2025 & 0.25527338286629103 & 0.79 \\
\hline 7 & 0.32 & 0.13 & 0.45 & 0 & 0 & 0.45 & 0.2025 & 0.25527338286629103 & 0.79 \\
\hline 8 & 0.32 & 0.13 & 0.45 & 0.32 & 0 & 0 & 0.1024 & 0.18152773892714028 & 0.56 \\
\hline 9 & 0.32 & 0.13 & 0.45 & 0.32 & 0 & 0 & 0.1024 & 0.18152773892714028 & 0.56 \\
\hline 10 & 0.32 & 0.13 & 0.45 & 0.32 & 0 & 0 & 0.1024 & 0.18152773892714028 & 0.56 \\
\hline 11 & 0.32 & 0.13 & 0.45 & 0.32 & 0 & 0 & 0.1024 & 0.18152773892714028 & 0.56 \\
\hline 12 & 0.32 & 0.13 & 0.45 & 0.32 & 0 & 0 & 0.1024 & 0.18152773892714028 & 0.56 \\
\hline 13 & 0.32 & 0.13 & 0.45 & 0.32 & 0 & 0 & 0.1024 & 0.18152773892714028 & 0.56 \\
\hline 14 & 0.32 & 0.13 & 0.45 & 0.32 & 0 & 0 & 0.1024 & 0.18152773892714028 & 0.56 \\
\hline 15 & 0.32 & 0.13 & 0.45 & 0.32 & 0 & 0 & 0.1024 & 0.18152773892714028 & 0.56 \\
\hline 16 & 0.32 & 0.13 & 0.45 & 0.32 & 0 & 0 & 0.1024 & 0.18152773892714028 & 0.56 \\
\hline \multicolumn{8}{|c|}{ Estimasi Waktu Pencarian } & $+1144 \mathrm{~ms}$ & \\
\hline
\end{tabular}

2. Hasil Pencarian Kedua

Berikut adalah rincinan perhitungan consine pertiap hadits berdasarkan keyword:

Tabel 5. Perhitungan Consine Pencarian kedua

\begin{tabular}{|c|c|c|c|c|c|c|c|c|c|}
\hline \multirow{2}{*}{ Hadits } & \multicolumn{3}{|c|}{ Wqk } & \multicolumn{3}{|c|}{ Wdk } & \multirow{2}{*}{$\begin{array}{l}\sum_{k=1}^{m} w q k \\
{ }^{*} \text { wdk }\end{array}$} & \multirow{2}{*}{$\sqrt{\sum_{k=1}(w q k)^{2}} \cdot \sqrt{\sum_{k=1}(w d k)^{2}}$} & \multirow{2}{*}{$\operatorname{Con}(\mathbf{q}, \mathbf{d})$} \\
\hline & Q1 & Q2 & Q3 & D1 & D2 & D3 & & & \\
\hline 1 & 0.32 & 0.13 & 0.45 & 0.32 & 0.13 & 0.45 & 0.3218 & 0.3218 & 1.0 \\
\hline 2 & 0.32 & 0.13 & 0.45 & 0.32 & 0 & 0.45 & 0.3049 & 0.31323604517998 & 0.97 \\
\hline 3 & 0.32 & 0.13 & 0.45 & 0 & 0.13 & 0.45 & 0.2194 & 0.26571209983739 & 0.83 \\
\hline 4 & 0.32 & 0.13 & 0.45 & 0 & 0 & 0.45 & 0.2025 & 0.25527338286629 & 0.79 \\
\hline 5 & 0.32 & 0.13 & 0.45 & 0 & 0 & 0.45 & 0.2025 & 0.25527338286629 & 0.79 \\
\hline 6 & 0.32 & 0.13 & 0.45 & 0 & 0 & 0.45 & 0.2025 & 0.25527338286629 & 0.79 \\
\hline 7 & 0.32 & 0.13 & 0.45 & 0 & 0 & 0.45 & 0.2025 & 0.25527338286629 & 0.79 \\
\hline 8 & 0.32 & 0.13 & 0.45 & 0 & 0 & 0.45 & 0.2025 & 0.25527338286629 & 0.79 \\
\hline 9 & 0.32 & 0.13 & 0.45 & 0 & 0.13 & 0 & 0.0169 & 0.07374564393915 & 0.23 \\
\hline 10 & 0.32 & 0.13 & 0.45 & 0 & 0.13 & 0 & 0.0169 & 0.07374564393915 & 0.23 \\
\hline 11 & 0.32 & 0.13 & 0.45 & 0 & 0.13 & 0 & 0.0169 & 0.07374564393915 & 0.23 \\
\hline 12 & 0.32 & 0.13 & 0.45 & 0 & 0.13 & 0 & 0.0169 & 0.07374564393915 & 0.23 \\
\hline 13 & 0.32 & 0.13 & 0.45 & 0 & 0.13 & 0 & 0.0169 & 0.07374564393915 & 0.23 \\
\hline 14 & 0.32 & 0.13 & 0.45 & 0 & 0.13 & 0 & 0.0169 & 0.07374564393915 & 0.23 \\
\hline
\end{tabular}

Estimasi Waktu Pencarian

$+893 m s$

3. Hasil Pencarian Ketiga

M. Fahri, dkk: Implementasi Algoritma.... 
Tabel 6. Perhitungan Consine Pencarian ketiga

\begin{tabular}{|c|c|c|c|c|c|c|c|c|c|}
\hline \multirow{2}{*}{ Hadits } & \multicolumn{3}{|c|}{ Wqk } & \multicolumn{3}{|c|}{ Wdk } & \multirow{2}{*}{$\begin{array}{l}\sum_{k=1}^{m} w q k \\
{ }^{*} w d k\end{array}$} & \multirow{2}{*}{$\sqrt{\sum_{k=1}^{m}(w q k)^{2}} \cdot \sqrt{\sum_{k=1}^{m}(w d k)^{2}}$} & \multirow{2}{*}{$\operatorname{Con}(\mathbf{q}, \mathrm{d}$} \\
\hline & Q1 & Q2 & Q3 & D1 & D2 & D3 & & & \\
\hline 1 & 0.32 & 0.13 & 0.45 & 0.32 & 0.13 & 0.45 & 0.3218 & 0.3218 & 1.0 \\
\hline 2 & 0.32 & 0.13 & 0.45 & 0.32 & 0 & 0.45 & 0.3049 & 0.3132360451799888 & 0.97 \\
\hline 3 & 0.32 & 0.13 & 0.45 & 0 & 0 & 0.45 & 0.2025 & 0.25527338286629103 & 0.79 \\
\hline 4 & 0.32 & 0.13 & 0.45 & 0.32 & 0 & 0 & 0.1024 & 0.18152773892714028 & 0.56 \\
\hline 5 & 0.32 & 0.13 & 0.45 & 0 & 0.13 & 0 & 0.0169 & 0.07374564393915074 & 0.23 \\
\hline 6 & 0.32 & 0.13 & 0.45 & 0 & 0.13 & 0 & 0.0169 & 0.07374564393915074 & 0.23 \\
\hline 7 & 0.32 & 0.13 & 0.45 & 0 & 0.13 & 0 & 0.0169 & 0.07374564393915074 & 0.23 \\
\hline 8 & 0.32 & 0.13 & 0.45 & 0 & 0.13 & 0 & 0.0169 & 0.07374564393915074 & 0.23 \\
\hline
\end{tabular}

\section{PENUTUP}

\subsection{Kesimpulan}

1. Algoritma Weighted Tree Similarity adalah sebuah algoritma untuk mencari nilai keserupaan(similarity) dengan menggunakan bentuk tree yang berbobot. terlihat bahwa, bentuk tree dari kitab alLu'lu' wa al-Marjan memiliki node berlabel diantaranya root node kitab, leaf node bab, perawi dan terjemahan.

2. Algoritma Boyer Moore memulai pencocokan karakter dari kanan. Dimisalkan ada sebuah usaha pencocokan yang terjadi pada text[i..i+n-1], anggap ketidak cocokan pertama terjadi di antara text $[\mathrm{i}+\mathrm{j}]$ dan pattern[j], dengan $0<\mathrm{j}<\mathrm{n}$. Berarti, teks $[i+j+1 . . i+n-1]=$ pattern $[j$ $+1 . . n-1]$ dan $a=$ teks $[i+j]$ tidak sama dengan $b=$ pattern[j].

3. Dari hasil pengujian yang dilakukan dengan tiga responde, android dan keyword yang berbeda, algoritma Weighted Tree Similarity mampu menampilkan urutan kemiripan data dari yang mendekati data pencarian hingga yang paling jauh dari data pencarian.

\subsection{Saran}

Dalam beberapa kasus algoritma atau aplikasi memerlukan beberapa jenis interaksi manusia. Dalam aplikasi ini dibutuhkan inputan berupa pilihan kitab dan memasukan keyword untuk bab perawi dan terjemahan. Hal ini bertujuan agar sistem menampilkan hadits yang dimaksud. Sehingga user tidak harus membuka satu per satu hadits pada daftar pencarian untuk menemukan hadits yang diinginkan. jika segmentasinya untuk user pada umumnya, hal ini dirasa sulit untuk sebagian user yang tidak mengetahui susunan kitab $\mathrm{Al} \mathrm{Lu'lu'} \mathrm{wal} \mathrm{Marjan.} \mathrm{Akan} \mathrm{lebih} \mathrm{mudah}$ jika terdapat opsi menonaktifkan pencarian kitab, bab dan perawi. Sehingga user cukup hanya menginput terjemahannya saja.

\section{DAFTAR PUSTAKA}

[1] Anggeriana, Herwin, 2011, Cloud Computing, Jurnal Teknik Informatika, Vol 1 September 2011

[2] Sarno, R., Anistyasari, Y., \& Fitri, R. 2012. Semantic Search. Yogyakarta:C.V Andi Offset.

[3] Kendall, K. E., \& Kendall, J. E. 2011. SYSTEM ANALYSIS AND DESIGN. New Jersey: Pearson Education, Inc

[4] Fu'ad Bin Abdul Baqi, Muhammad. Mutiara Hadits Shahih Bukhari Muslim. [online] (https://ibnumajjah.com/2013/03/04/allulu-wal-marjan diakses tanggal 16 September 2017 pukul 10:54 WIB)

[5] Rahutomo, F. 2009. Tesis. Penerapan Algoritma Weighted Tree Similarity Untuk Pencarian Semantik Wikipedia. Institut Teknologi Sepuluh November.

[6] Yuthika, Dian. 2014. Implementasi Algoritma Porter Stemmer dan AlgoritmaBoyer Moore Pada Pencarian Ensiklopedia Etika Islam Berdasarkan AlQur'an dan Hadits. Jakarta: Universitas Islam Negeri Jakarta Syarif Hidayatullah. 